Volume 2, No 2, Agustus 2021

\title{
KONTRIBUSI PEMIKIRAN SOSIALISME ILMIAH KARL MARX DAN SOSIO EKONOMI AL-GHAZALI UNTUK EKONOMI DUNIA
}

\author{
Misbahul Ali \\ memesaly78@gmail.com
}

\begin{abstract}
ABSTRAK
Perekonomian merupakan salah satu pilar yang sangat menentukan dalam kehidupan ini. Kondisi ekonomi yang stabil telah menjadi simbol dari kemajuan sebuah bangsa. Sebab sejarah telah membuktikan bahwa kondisi ekonomi yang stagnan, sesungguhnya akan lebih tepat jika dikatakan sebagai gerbang keterbelakangan. Dalam perjalanannya, ternyata aktivitas ekonomi yang dijalankan justru rentan menimbulkan sebuah 'ironi' dengan munculnya budaya eksploitasi sebagai sarana untuk mengeruk laba sebanyak-banyaknya. Hal ini sering dipraktekkan oleh para pemilik modal terhadap para kaum bawahan. Tentu saja fakta tersebut membuat para kaum intelek merasa terpancing untuk merefleksikan rasa kepeduliannya dengan melakukan 'resistensi intelektual' untuk menumpas ketidakadilan yang menimpa masyarakat bawah. Inilah yang coba ditunjukkan oleh Karl Marx dengan pemikiran sosialisme-ilmiahnya dan alGhazali dengan sosio-ekonominya. Dalam tulisan ini disimpulkan bahwa Soslialisme-ilmiah Karl Marx merupakan paham sosialisme yang bertujuan untuk mewujudkan keadilan sosial-ekonomi bagi para kelas pekerja yang didasarkan atas pengetahuan objektif tentang hukum-hukum perkembangan masyarakat. Sedangkan apa yang dimaksud sosio-ekonomi al-Ghazali adalah konsep pemikiran yang lebih bersifat normatif, yang didalamnya menekankan adanya apresiasi yang tinggi terhadap nilai-nilai etika religius dalam melaksanakan kegiatan ekonomi. Yakni sebuah konsep ekonomi yang menjadikan mashlahah sebagai tujuan utamanya dengan berlandaskan pada pemeliharaan Maqaashid al-Syari'ah al-Khamsah.
\end{abstract}

Jurnal al-Idārah | 90 
Volume 2, No 2, Agustus 2021

\section{Kata kunci : Sosialisme-ilmiah Karl Marx, sosio-ekonomi Al-Ghazali, Ekonomi Dunia}

\section{PENDAHULUAN}

Barang kali kita sepakat jika dikatakan bahwa sektor ekonomi merupakan salah satu elemen vital dalam alur kehidupan manusia. Kitapun tak bisa mengelak dari satu kenyataan dimana pertumbuhan ekonomi telah menjadi simbol kemajuan suatu Negara. Sejarah membuktikan, satu di antara pilar yang dapat menyangga kontruksi peradaban sebuah bangsa adalah terletak pada bidang perekonomiannya yang telah maju. Tak salah jika akhirnya muncul sebuah aksioma yang meneriakkan bahwa kondisi ekonomi yang stagnan akan lebih tepat jika dikatakan sebagai gerbang keterbelakangan. Dalam paham determinisme dijelaskan bahwa sektor ekonomi merupakan inti yang menentukan kehidupan masyarakat, sehingga perombakan serta perbaikan ekonomi sebagai infrastruktur masyarakat akan melahirkan perombakan dan perbaikan kehidupan sosial. Oleh karena itu sangatlah wajar bila setiap Negara saling bahu-membahu untuk mencapai tingkat perekonomian dalam intensitas tertinggi. (Andi Muawiyah Ramly, 2013).

Bukan itu saja, dalam perkembangannya dunia ekonomi tidak hanya menjadi ajang peningkatan kualitas hidup. Namun lebih dari itu, keberadaannya justru lebih tampak sebagai sebuah refleksi ideologis dari suatu kelompok yang mesti diperjuangkan. Sehingga yang terjadi bukan saja aktivitas ekonomi secara murni, akan tetapi upaya mempertahankan nilai ideologi terkadang terkesan lebih dominan. Dari sini kemudian muncullah dua kutub besar aliran ekonomi, yakni kapitalisme barat dan sosialisme timur. Namun belakangan ini muncul satu lagi aliran baru, yaitu sosialisme demokratis yang dikenal dengan sebutan Jalan Ketiga (The Third Way), yang pertama kali diperkenalkan oleh Antony Giddens. (Fauz Noor, 2015)

Sebagaimana telah diketahui, kapitalisme barat sangat mendewakan uang. Kapitalisme menancapkan satu keyakinan bahwa gerak ekonomi sepenuhnya bergantung kepada mekanisme pasar. Pada akhirnya terjadilah eksploitasi besar-besaran dengan 
kepemilikan uang (modal) pada segelintir orang saja. Sementara para kaum bawahan semakin terpuruk dalam dinginnya peti kemiskinan.

Namun ketika masyarakat dunia dininabobokkan oleh kekuatan kapitalisme yang meneriakkan hak asasi manusia sebagai mantra ajaibnya, bangkitlah manusia-manusia revolusioner yang menentang aksi penindasan yang secara rapi dilakukan oleh para kaum kapitalis. Di antara mereka yang paling berpengaruh adalah Karl Marx. Ia muncul ke permukaan sebagai "protagonista" atau dewa penyelamat bagi para kaum buruh yang sebelumnya menjadi objek perbudakan ekonomi oleh para pemilik modal. Sebagaimana Erich Fromm menulis, "Cita-cita Marx sesungguhnya adalah membebaskan manusia dari rantai ketergantungan alienasi dan perbudakan ekonomi." (Fauz Noor, 2012)

Dengan bendera sosialisme-ilmiah yang diusungnya, Marx bercita-cita bagaimana manusia terbebas dari belenggu eksploitasi ekonomi-politik yang telah cukup membuat para kaum buruh tertindas. Dia tidak bisa menerima begitu saja bila ternyata yang kekar selalu benar, yang senag selalu menang, yang kuat selalu dapat, yang akhirnya dengan uang kebenaran menjadi terbuang.

Dengan semangat berapi-api Marx menyalakan obor perlawanan kepada siapa saja, terutama kaum kapitalis, yang menjadikan para kaum lemah sebagai objek eksploitasi. Secara lantang ia meneriakkan keinginannya menciptakan pola kehidupan sosial yang terbebas dari kepemilikan pribadi atas alat-alat produksi, yang mana hak milik ini secara niscaya memungkinkan kaum kelas atas dapat hidup dari penghisapan tenaga kerja kelas bawah. Dari sini Marx mengasumsikan bahwa pembebasan manusia dari segala bentuk penindasan hanya dapat tercapai apabila bendera sosialisme sudah didirikan. (Franz Magnis Suseno, 2016)

Sekarang kita coba menerawang pada lembaran sejarah yang lebih lampau. Sekitar abad $11 \mathrm{M}$, keadaan yang hampir serupa dengan dominasi aroma kapitalisme juga pernah merajalela, di mana prilaku ekonomi para kaum beruang secara sadis membantai eksistensi nilai kemunisaan, yang mana hal ini di rasakan begitu perih oleh lapisan masyarakat bawah. Lebih parah lagi, saat itu kemegahan nilai etika-moral benar-benar terpasung oleh superioritas penguasa dinar dan dirham yang enggan memperhatikan ketentuan-ketentuan syari'ah. Tak pelak lagi, kesenjangan sosial yang begitu curam seolah menjadi mimpi buruk 
yang sangat mengerikan bagi para kaum miskin. Akhirnya kegelisahan intelektual dari para ilmuan kala itu bermunculan sebagai reaksi atas ketidakadilan tersebut. (Adiwarman Azwar Karim, 2012).

Diantaranya adalah apa yang dimunculkan oleh al-Ghazali dengan investasi saham intelektualnya. Secara lantang ia mengecam perilaku ekonomi para kaum elit yang dirasa telah melenceng jauh dari koridor agama. Aktifitas konsumsi yang berlebihan seolah telah menjadi simbol yang semakin memperkukuh status sosial mereka di hadapan kenestapaan para fakir miskin. Kenyataan tersebut membuat naluri intelektual al-Ghazali merasa terpanggil untuk setidaknya menetralisir kondisi tatanan sosial yang saat itu telah mencapai titik kronis. (Afzalur Rahman, 2015)

Dalam salah satu karyanya al-Adab fi al-Din, al-Ghazali menegaskan bahwa tatanan sosial-ekonomi masyarakat dapat kembali pada titik keseimbangannya bila para kaum kaya raya itu mampu menunjukkan pola sikap yang mencerminkan kemuliaan akhlak sebagaimana layaknya manusia yang beragama. Sikap tawadlu', sederhana, kesadaran untuk mengayomi para fakir miskin serta senantiasa mensyukuri nikmat Tuhan, merupakan hal yang selayaknya diperagakan oleh para kaum kaya demi mengembalikan kehidupan masyarakat pada harmoni yang dicita-citakan agama. (Abu Hamid al-Ghazali, 1996)

Kemudian dengan kapasitas keilmuannya yang tak diragukan lagi, ia berusaha menawarkan sebuah kerangka pemahaman yang akan mengembalikan para kaum kaya pada kesadaran ilahiahnya. Hal ini tentu tak lepas dari corak pemikiran al-ghazali yang lebih didominasi dengan paradigma tasawwuf. Dari situ ia menegaskan bahwa aktifitas ekonomi selayaknya dilakukan dengan dilandasi nilai-nilai etika religius. Sebab menurut pandangannya, kegiatan ekonomi merupakan bagian dari pemenuhan tugas keagamaan bagi setiap individu. Jelaslah bahwa ia sangat menginginkan terwujudnya atmosfer sosial yang senantiasa menjaga kemegahan nilai-nilai transenden. Sehingga segala bentuk aktivitas yang dilakukan oleh setiap individu lebih diarahkan pada pencapaian kesejahteraan sosial. Karena itulah al-Ghazali menentang habis-habisan tindakan eksploitasi ekonomi yang secara sadis membantai kelestarian nilai-nilai kemanusiaan. (Abu Hamid al-Ghazali, $\mathrm{tt}$ ).

Namun demikian, pemikiran sosio-ekonomi al-Ghazali yang berakar pada konsep yang dikenal dengan istilah "Fungsi Kesejahteraan Sosial Islami", juga menitikberatkan 
pada kesadaran setiap individu untuk meningkatkan kualitas perekonomiannya secara personal. Karena itu pula ia mengritik keras terhadap mereka yang usahanya hanya terbatas untuk memenuhi kebutuhan penyambung hidupnya saja. Menurutnya tindakan semacam itu akan menghambat aliran daya kreatifitas yang tentunya akan berimplikasi pada menurunnya gairah aktifitas masyarakat secara keseluruhan. Bila ini benar-benar terjadi, maka eksistensi agama ikut terancam, sebab kehidupan dunia adalah tangga menuju kehidupan akhirat yang merupakan puncak destinasi dari ajaran agama. (Adiwarman Azwar Karim, 2013).

Dari gambaran singkat diatas, akan menjadi bahan kajian yang sangat menarik bila kita mencoba untuk membandingkan corak pemikiran kedua tokoh besar tersebut, yakni Karl Marx dan al-Ghazali, mengingat latar belakang pribadi mereka yang bertolak belakang. Di mana kita mengenal bahwa Karl Marx sebagai seorang anti tuhan sementara al-Ghazali merupakan tokoh sufi Islam, namun mereka memiliki wajah pemikiran ekonomi yang nyaris seirama. Dari sini pula kita dapat melihat adanya pertemuan yang cukup unik antara corak pemikiran ekonomi barat dan corak pemikiran ekonomi Islam yang salama ini terkesan berhadap-hadapan secara diametral. Kenyataan inilah yang membuat gairah intelektual kami (penulis) merasa terdorong untuk mengkaji lebih mendalam alur pemikiran kedua tokoh tersebut untuk kemudian membandingkannya sehingga akan didapatkan titik persamaan dan perbedaan yang substansial dari keduanya.

\section{Riwayat Hidup Karl Marx}

Kota Trier atau biasa disebut dengan Traves, sebuah daerah yang termasuk kawasan Rheiland Jerman (Prusia), tercatat sebagai kota yang bersejarah dalam literatur filsafat. Karena di daerah inilah pada 5 Mei 1818 Karl Heinrich Marx dilahirkan. Kedua orang tuanya adalah keturunan pendeta-pendeta Yahudi. Ayahnya, Heinrich Marx termasuk golongan menengah dan menjadi pengacara ternama di Traves. Sedang ibunya adalah puteri seorang pendeta Belanda yang juga berbangsa Yahudi. Berdasarkan nasab semacam ini, banyak penulis yang sering menghubungkan kejeniusan Karl Marx dengan darah Yahudi yang mengalir di tubuhnya. (Andi Muawiyah Ramly, 2013).

Pada tahun 1824, yakni ketika Marx berusia 6 tahun, seluruh keluarganya mengalami converse (perpindahan) agama dari Yahudi ke agama Kristen Protestan. 
Peristiwa ini membekas dalam perjalanan hidup Marx selanjutnya. Bagaimanapun dengan perpindahan agama ini maka turut berubah pula keyakinan keluarga Marx dari bertuhan Yahova yang Esa kepada keyakinan Trinitas. (Andi Muawiyah Ramly, 2013). Perpindahan agama ini pertama kali di lakukan oleh ayahnya yang kemungkinan besar dilakukannya agar ia dapat menjadi pegawai negeri, tepatnya notaris, di Prussia yang berhaluan Protestan. Baru kemudian ibu Marx menyusul yang mungkin sebenarnya tidak ingin pindah agama. Bisa jadi kenyataan begitu mudahnya ayah Karl Marx berpindah agama menjadi alasan mengapa Marx tidak pernah meminati masalah agama. (Franz Magnis Suseno, 2016).

Pada usia 17 tahun, Marx menamatkan sekolah menengah (Gymnasium) di Treves tepatnya tahun 1835. Kemudian atas dasar perintah ayahnya, Marx melanjutkan pelajarannya di fakultas Hukum Universitas Bonn selama satu tahun. Di sini Marx tidak kerasan dan kemudian pindah ke Universitas Berlin dengan mengkhususkan diri mempelajari filsafat dan sejarah seperti yang dicita-citakannya sejak semula. Di Universits Berlin inilah baru kelihatan bakatnya yang luar biasa dalam filsafat. Akhirnya pada usia 23 tahun Karl Marx memperoleh gelar doktor dalam ilmu filsafat dengan judul disertasi The Difference Between the Natural Philosophy of Democritos and Natural Philosophy of Epicurus (Perbedaan antara Filsafat Alam Demokritus dan Fisafat Alam Epicurus), disertasi ini diajukan di Universitas Jena 5 April 1841. (Andi Muawiyah Ramly, 2013).

Perjalanan karir seorang filosof yang mendambakan kebebasan berpikir dan tidak ingin diikat oleh institusi-institusi di sekitarnya, sering menjadi boomerang yang menghantam pemiliknya. Demikian pula halnya dengan Karl Marx, semula ia berkeinginan menjadi seorang dosen sebagai tonggak dalam karir akademi. Namun rencananya itu terpaksa dibatalkan karena pahamnya yang radikal dan tak mudah berkompromi dengan Status Quo yang berlaku pada saat itu. Karena gagal merintis karir dosen, Marx menerjunkan diri sebagai wartawan. Hal ini dimungkinkan karena golongan radikal pada waktu itu menerbitkan majalah oposisi di Koln dengan nama Rheinissche Zeitung (Rhine Gazette). Marx menjadi penyumbang pertama majalah ini dan menulis sebuah artikel tentang kaum tani Jerman. Bulan Oktober 1842 Marx pindah ke Koln untuk menjabat sebagai pemimpin redaksi. Karena kritiknya terlalu keras terhadap pemerintah, maka akhirnya majalah ini diberangus setelah terbit satu tahun. Dan Marx bersama Arnold Ruge 
pindah ke Paris menerbitkan majalah yang tidak kalah kerasnya bernama DeutscheFranzosische Jahrbucher (Franco-German Year Books). Di negeri inilah Marx mulai mempelajari secara sungguh-sungguh masalah sosialisme dan berkenalan dengan pemimpin-pemimpin sosialis bawah tanah Prancis. Benih-benih pemikiran komunis dan tekad revolusi juga bermula di negeri ini. (Andi Muawiyah Ramly, 2013).

Pada tahun 1844 terjadi sebuah kejadian penting dalam sejarah kehidupan Karl Marx, yaitu pertemuannya dengan Frederick Engels (1820-1895), seorang anggota gerakan sosialis yang datang dari London. Engels, anak seorang pengusaha pabrik pemintal kapas juga seorang Jerman kelahiran Bremen. Walaupun terdapat perbedaan latar belakang keluarga, pendidikan maupun filsafat, namun kedua orang ini bersahabat seumur hidup sebuah persahabatan yang patut dicatat dalam sejarah dunia. Jiwa revolusioner dan ketidaksanggupan melihat penderitaan manusia yang mereka miliki mampu megikat keduanya. Pada ujungnya sulit menyebut salah seorang dari mereka dengan meninggalkan yang lain. Awal persahabatan abadi ini ditandai dengan penulisan buku bersama, suatu hal yang masih langka di kalangan cendikiawan waktu itu. Buku yang di tulis berjudul Die Heilige Familie (The Holy Family). (Jon Elster, 2000).

Sebagai akibat dari tulisan dan agitasi Marx di majalah Vorwarts, penguasa Jerman meminta kepada pemerintah Prancis agar Marx diusir. Marx pun diusir dari Prancis sebagai orang asing yang tidak dikehendaki (persona grata) dan pindah ke Brussel bersama keluarganya. Karena sakit hati inilah Marx melepaskan status kewarganegaraannya sebagai warga Negara Jerman. Selama di Brussel Marx memperdalam studi ekonomi dan menjalin kontak dengan organisasi-organisasi buruh, dan secara intensif terlibat dalam diskusidiskusi serta protes kaum pekerja. Dengan ringkas di gambarkan oleh Robert Downs "kemana saja Marx pergi, ia adalah seorang tukang pidato yang garang dan aktif; ia mengorganisir gerakan buruh; ia memimpin penerbitan komunis dan menganjurkan pemberontakan." (Andi Muawiyah Ramly, 2013).

Akhirnya, pada tahun 1867, terbitlah buku pertama dari karya Marx yang dimaksudkan untuk membuktikan kebenaran ramalannya tentang kehancuran kapitalisme dan keniscayaan sosialisme, buku tersebut berjudul Das Capital, yang buku kedua dan ketiganya baru diterbitkan oleh Engels setelah Marx meninggal dunia. Meskipun Das 
Capital mengecewakan banyak teman Marx - dianggap terlalu kering dan tidak jelas maksudnya - namun Marx semakin dikenal dikalangan para pemimpin gerakan buruh di benua Eropa. Pada tahun 1864 wakil-wakil berbagai partai buruh nasional telah mendirikan Asosiasi Buruh Internasional Pertama, Marx pun turut dalam dewan pimpinannya. Melalui asosiasi ini Marx dapat berhubungan dengan gerakan-gerakan buruh terpenting di Eropa walaupun ia sendiri tidak pernah menduduki jabatan pimpinan. Ia sering dikunjungi dan dimintai nasehat. Kegiatan asosiasi terebut ditandai dengan konflik yang semakin tak terdamaikan antara Marx di satu pihak dan sayap anarkistik di bawah Mikail Bakunin di lain pihak. Karena konflik itu, sembilan tahun kemudian asosiasi tersebut membubarkan diri. (Franz Magnis Suseno, 2016).

Di balik sepak terjangnya yang spektakuler dalam dunia intelektual dan gerakan, Marx menyimpan guratan kehidupan pribadi yang kurang beruntung. Walaupun kehidupan berkeluarga dengan istrinya cukup bahagia, namun ia terus- menerus didera kemelaratan, bahkan sering kurang makan. Salah seorang anaknya mati karena kurang makan dan istrinya sering bereaksi histeris. Marx tidak memiliki pendapatan yang tetap dan tidak tahu bagaimana berurusan dengan uang. Hanya karena kiriman bantuan dari Engels (yang memiliki sebuah pabrik tekstil di Manchester) mereka dapat bertahan. Apalagi Marx suka bersikap otoriter dan menyinggung perasaan orang lain, terutama rekan-rekan sosialisnya. Siapa yang tidak tunduk pada kepemimpinan teoretisnya akan diserang dengan gaya menghina, termasuk menjelekkan nama pribadi mereka. Karena itulah hubungannya dengan hampir semua teman seperjuangannya lama-kelamaan ambruk. Hanya persahabatannya dengan Engels yang tetap bertahan. Sejak tahun 1860-an Engels mampu menyediakan kiriman uang bulanan tetap bagi Marx sehingga 20 tahun terakhir keluarga Marx relatif bebas dari kesulitan ekonomis. (Franz Magnis Suseno, 2016).

Pada 2 Desember 1881, Marx kehilangan istrinya yang selama ini menyertai dalam suka dan duka sepanjang 40 tahun yang meninggal dunia setelah mengidap penyakit tanpa pengobatan yang cukup. Marx tidak dapat mengantarkan istrinya ke pekuburan karena sakit 
parah. Ketika Engels mengunjunginya, sahabatnya ini berkomentar bahwa "The Moor ${ }^{l}$ is Dead too." (Andi Muawiyah Ramly, 2013).

Sosok Marx setelah istrinya meninggal memang semakin lemah. Namun satu hal yang patut dicatat, sepanjang mengenai dirinya akan terlihat bahwa ia sanggup memadukan dua buah aktivitas, yaitu studi mendalam yang ujungnya membuahkan seperangkat teori serta tindakan aktif dalam organisasi kaum buruh sebagai realisasi praksis dari teorinya. (Peter Beilharz, 2012).

Di pagi 14 Maret 1883 seperti biasanya Marx mengunjungi kamar studinya, beberapa saat kemudian baru diketahui bahwa ia telah meninggal di atas kursi di depan meja belajarnya. Layar kehidupan telah ditutup baginya, tetapi sulit mangatakan kalimat yang sama pada ajaran dan ide-ide yang ditinggalkannya. (Andi Muawiyah Ramly, 2013). Literatur dunia memberikan penilaian dari sisi pandangan yang beragam. Namun sulit mencari daerah tengah di antara pandangan yang menganggap ia sebagai Yahudi yang diilhami iblis yang ingin menghancurkan peradaban, dan gambaran yang mengatakan bahwa Marx sebagmai seorang yang mengabdikan dirinya untuk kelas tak berpunya dengan tidak memperdulikan diri dan keluarganya. (M.T. Ritonga, 2000)

\section{Karya-karya Karl Marx di Bidang Ekonomi}

Satu hal yang tak dapat kita tinggalkan dalam kajian ini, yaitu mengenali untuk kemudian mendalami percikan gagasan seorang Marx yang tertuang dalam serpihan karyakaryanya. Hal ini sangatlah perlu agar kita dapat lebih mendekati wilayah terdalam dari zona intelektual sosok Karl Marx. Dari sini akan sangat memungkinkan bagi kita meraih wawasan yang utuh tentang pemikiran Marx, sehingga apa yang kita dapatkan bukan sekedar fragmentasi yang justru akan membawa "Marx yang sebenarnya" pada wajah ambiguitas.

Dalam perjalanan karirnya sebagai seorang pemikir ulung, Marx telah menghasilkan karya-karya yang meliputi tiga kategori, yaitu filsafat, sejarah dan politik serta ekonomi. Di samping itu ada beberapa karya Marx yang berupa pamflet, manuskrip, kumpulan surat,

\footnotetext{
1 "The Moor" adalah julukan untuk Marx semasa kanak-kanak yang berarti "si Maroko", sejenis bangsa yang mendiami Afrika Barat Laut. Julukan tersebut disematkan pada Marx kecil disebabkan kulitnya yang hitam, mata cekung tapi bersinar dengan tajam. Perawakan tubuhnya gemuk meski termasuk pendek dibanding anakanak Jerman yang sebaya dengannya ketika usia 15 tahun. (Andi Muawiyah Ramly, 2013)
} 
dan sejumlah esai yang baru ditemukan dan diterbitkan sesudah ia meninggal dunia. Namun dalam penulisan skripsi ini kami hanya ingin menyajikan karya-karya Marx di bidang ekonomi agar alur pembahasannya tidak terlalu melebar. Berikut karya-karya Marx yang secara khusus dan eksklusif mencerminkan kedalaman lembah intelektualitasnya di bidang ekonomi : (Andi Muawiyah Ramly, 2013).

a. "Lohnarbeit und Kapital," (1849), dimuat dalam Neue Rhenische Zeitung, 5-11 April 1849, terbit di Jerman dengan judul Wage, Labour and Capital (Berlin: 1891).

b. Grundrisse der Kritik der Politischen Okonomie (1857-1865), beberapa bagian diterjemahkan dengan judul Pre-capitalist Ekonomic Formation (New York: 1965).

c. Zur Kritik der Politischen Okonomis (1859), diterjemahkan oleh N. I. Stone, A Contribution to The Critique of Political Economy (New York: 1904).

d. Theorien uber den Mehrwert (1861-1863), diedit oleh Karl Kautsky (Stuttgart: 19051909), terbit di Amerika, Theories of Surplus Value (New York: 1952).

e. Wage, Price and Profit (1865), pamflet yang ditulis untuk perkumpulan Kaum Pekerja Internasional. Publikasi pertama diedit oleh Elanor Marx Aveling (London: 1898), kemudian Institut Marxist-Leninist yang menerbitkan kembali dengan judul yang sama, (Moscow: 1963).

f. Das Capital, Kritik der Politischen Okonomis (1850-1866), sebuah karya monumental dan termasuk salah satu buku yang merubah dunia "books that changed the world". Ketika ditulis menghabiskan waktu selama tujuh belas tahun, diterjemah sebanyak tiga volume. Terjemahan awal (Moscow: 1872, France: 1875), kemudian S. Moore dan E. Aveling, Capital (London: 1887). Vol. I.

g. The Process of Capitalist Production. Vol. II. The Process of Circulation Capital. Vol. III. The Process of Capitalist Production as a Whole. Vol. I. Dalam bahasa Jerman (1867) sampai cetakan keempat diberi kata pengantar oleh Marx. Sedang Vol. II dan Vol. III dikerjakan oleh Engels dengan berpedoman manuskrip yang ditinggalkan sahabatnya. 


\section{Riwayat Hidup Abu Hamid al-Ghazali}

Hujjatul Islam Abu Hamid Muhammad bin Muhammad al-Tusi al-Ghazali ${ }^{2}$ lahir di Tus, sebuah kota kecil di Khurosan, Iran, pada tahun 450 H/1058 M. sejak kecil, Imam alGhazali hidup dalam lingkungan yang kental dengan nuansa tasawwuf. Ia tumbuh dan berkembang dalam asuhan seorang sufi, setelah ayahnya yang juga seorang sufi meninggal dunia.

Sejak usia belia, al-Ghazali memang memiliki antusiasme yang tinggi terhadap ilmu pengetahuan. Ia pertama-tama belajar bahasa Arab dan fiqh di kota Tus, kemudian pergi ke kota Jurjan untuk belajar dasar-dasar ilmu Ushul Fiqh. Setelah kembali ke kota Tus setelah beberapa waktu, ia pergi ke Naisabur untuk melanjutkan petualangan ilmiahnya. Di kota ini al-Ghazali belajar kepada al-Haramain Abu al-Ma'ali al-Juwaini, sampai yang terakhir ini wafat pada tahun 478 H/1085 M. (Misbahul Munir dan A. Djalaluddin, 2014).

Setelah itu ia berkunjung ke Baghdad, ibu kota Daulah Abbasiyah, dan kemudian bertemu dengan Wazir Nizham al-Mulk. Darinya al-Ghazali mendapat penghormatan dan penghargaan yang begitu besar. Pada tahun 483 H/1090 M, al-Ghazali diangkat menjadi guru di Madrasah Nizhamiyah. Pekerjaannya ini ia laksanakan dengan sangat berhasil, sehingga para ilmuan pada masa itu menjadikannya sebagi referensi utama.

Selain mengajar, al-Ghazali juga melakukan bantahan-bantahan terhadap berbagai pemikiran Bathiniah, Islamiyah, filosof dan lain-lain. Pada masa ini, sekalipun telah menjadi guru besar, ia masih merasakan kehampaan dan keresahan dalam dirinya. Akhirnya, setelah merasakan bahwa hanya kehidupan sufistik yang mampu memberikan penawar untuk memenuhi rasa dahaga ruhaniahnya, maka tanpa ada setitik keraguan pun yang bersarang dalam hatinya al-Ghazali memutuskan untuk menempuh jalur tasawwuf sebagai jalan hidupnya. (Marthon, Said Sa'ad, 2017).

Oleh karena itu, pada tahun 488 H/1095 M, al-Ghazali meninggalkan Baghdad dan pergi menuju Syiria untuk merenung, membaca, dan menulis selama kurang lebih 2 tahun. Kemudian ia pindah ke Palestina untuk melakukan aktivitas yang sama dengan mengambil tempat di Baitil Maqdis. Setelah menunaikan ibadah haji dan menetap beberapa waktu di

\footnotetext{
${ }^{2}$ Kata 'al-Ghazali' berasal dari kata ghazzal yang berarti pemintal benang, yang dinisbatkan pada pekerjaan ayahnya. Kata tersebut juga dapat berasal dari kata Ghazalah yang dinisbatkan pada kampung kelahirannya.
} 
kota Iskandariyah, Mesir, al-Ghazali kembali ke tempat kelahirannya, Tus, pada tahun 499 H/1105 M untuk melanjutkan aktivitasnya, yakni berkhulwat dan beribadah. Proses pengasingannya tersebut berlangsung selama 12 tahun, dan dalam masa ini, ia banyak menghasilkan karya-karyanya yang terkenal, termasuk diantaranya adalah karyanya yang monumental Ihya' Ulum al-Din.

Pada tahun yang sama, atas desakan penguasa pada masa itu, yaitu Wazir Fakhr alMulk, al-Ghazali kembali mengajar di Madrasah Nizhamiyah di Naisabur. Namun pekerjaannya itu hanya berlangsung selama dua tahun. Ia kembali ke kota Tus untuk mendirikan sebuah Madrasah bagi para Fuqaha' dan Mutashawwifin. Al-Ghazali memilih kota ini sebagi tempat menghabiskan waktu dan energinya untuk menyebarkan ilmu pengetahuan, hingga akhirnya ia meninggal dunia pada tanggal 14 Jumadil Akhir $505 \mathrm{H}$ atau bertepatan dengan tanggal 19 Desember 1111 M. (Adiwarman Azwar Karim, 2012).

Sekedar untuk diketahui, di dunia Barat al-Ghazali dikenal dengan nama "Algazel" dan sering dibandingkan dengan Thomas Aquinas. ${ }^{3}$ Kitabnya Ihya' Ulum al-Din sering pula dibandingkan dengan Summa Theologica-nya Thomas Aquinas. (M. B. Hendrie Anto, 2013).

\section{Serpihan-serpihan Karya Sang Hujjatul Islam}

Sejarah mencatat bahwa al-Ghazali merupakan sosok ilmuan dan penulis yang sangat produktif. Berbagai tulisannya telah banyak menarik perhatian dunia, baik dari kalangan Muslim maupun non-Muslim. Para pemikir Barat abad Pertengahan, seperti Raymond Martin, Thomas Aquinas, dan Paschal, ditengarai banyak dipengaruhi oleh pemikiran al-Ghazali. Pasca periode sang Hujjatul Islam ini, berbagai karyanya yang telah banyak diterjemahkan ke dalam berbagai macam bahasa, seperti Latin, Spanyol, Yahudi, Prancis, Jerman dan Inggris, dijadikan referensi oleh kurang lebih 44 pemikir barat. AlGhazali, diperkirakan telah menghasilkan 300 buah karya tulis yang meliputi berbagai disiplin ilmu, seperti filsafat, logika, moral, tafsir, fiqh, ilmu-ilmu al-Qur'an, tasawwuf, politik, administrasi, dan perilaku ekonomi. (Adiwarman Azwar Karim, 2012).

\footnotetext{
${ }^{3}$ Thomas Aquinas adalah salah satu tokoh aliran kaum skolastik: sebuah aliran pemikiran ekonomi yang beranggotakan orang-orang terpelajar abad pertengahan yang berlandaskan logika Aristoteles. Aliran ini menekankan pada kuatnya hubungan ekonomi dengan masalah etika serta masalah-masalah keadilan. Hal ini disebabkan karena tokoh-tokohnya dipengaruhi dengan kuat oleh ajaran Gereja. (M. T. Ritongga, 2000: 5)
} 
Namun demikian, yang ada hingga kini hanya 84 buah. Diantaranya adalah Ihaya' Ulum al-Din, al-Munqidz min al-Dlolal, Thafut al-Falasifah, Minhaj al-Arifin, alMustashfa min 'Ilm al-Ushul, Mizan al-'Amal, Misykat al-Anwar, Kimia al-Sa'adah, alWajiz, Syifa al-Ghalil, al-Thibr al-masbuk fi Nasihat al-Muluk, al-Hikmah $f i$ Makhluqotillah, Mi'raj al-Salikin, Raudlah al-Thalibin wa 'Umdatu al-Salikin, Qawa'id al'Aqa'id fi al-Tauhid, Khalashatu al-Tashanif fi al-Tashawwuf, al-Qisthas al-Mustaqim, alRisalah al-Wa'dziyah, Bidayah al-Hidayah, al-Kasyfu wa al-Tabyin, al-Mawa'idz fi alAhadits al-Qudsiyah, Iljam al-'Awam 'an 'Ilm al-Kalam, al-Ajwibah al-Ghazaliyah fi alMasa'il al-Ukhrawiyah, al-adab fi al-Din, Sirr al-'Alamain wa Kasyfu Ma fi al-Darain dan sebagainya. (Abu Hamid al-Ghazali, 1996).

Diantara sekian banyak serpihan-serpihan karya al-Ghazali, ada beberapa di antaranya yang secara gamblang menyuguhkan jernihnya pantulan cahaya pemikiran alGhazali yang berhubungan masalah ekonomi, misalnya Ihya' Ulum al-Din, al-Mustashfa, Mizan al-'Amal dan al-Tibr al-Masbuk fi Nasihat al-Muluk. (Adiwarman Azwar Karim, 2012).

\section{PEMIKIRAN SOSIALISME-ILMIAH KARL MARX DAN PEMIKIRAN SOSIO- EKONOMI AL-GHAZALI}

\section{A. Sosialisme-ilmiah: Sebuah cita-cita mulia}

Jika kita simak tentang bagaimana peta pemikiran Karl Marx dengan sosialismeilmiahnya, muncul satu kesan bahwa Marx merupakan tipe pemikir pragmatis namun tak mudah untuk dipahami begitu saja. Terkadang 'seolah-olah' kita membutuhkan pahat dan palu untak dapat memahami apa yang dimaksud dari pikiran-pikirannya. Tak heran bila kemudian lahir berbagai macam penafsiran tentang bagaimana ia membangun sebuah ideologi pemikiran dalam kiprahnya sebagai seorang filosof. Namun yang jamak kita temukan dan kita ketahui, Marx adalah seorang pimikir yang berideologi komunis yang 'emoh' dengan doktrin-doktrin dogmatis. Tudingan ini didasarkan pada satu pernyataan Marx yang cukup populer di kalangan kaum intelektual, "Agama adalah candu masyarakat". Padahal dalam hal ini patut kita perhatikan komentar Ali Syari'ati yang menilai bahwa pernyataan Marx tersebut merupakan kata-kata seorang intelek yang mencoba bangkit untuk melawan ketidakadilan. Agama selalu manjadi candu masyarakat 
memanglah tepat. Namun agama apakah yang dimakasud Marx? Menurut Syari'ati agama yang dimaksud adalah agama realitas yang ada dalam bentangan sejarah dimana Marx hidup yang kemudian dianalisis secara kritis. Ia melihat bahwa pada saat itu agama telah meninabobokkan manusia dalam dinginnya peti kejumudan. Ia juga menilai bahwa agama lebih berperan sebagai faktor untuk membenarkan dominasi sosial dan ekonomi kelompok minoritas atas kelompok mayoritas. Jadi secara substansial sebenarnya Marx tidak menentang agama, akan tetapi ia hanya mengkritisi secara ilmiah prilaku para tiran sosialekonomi yang secara lancang dan memalukan mengatasnamakan agama dalam setiap tindakannya. (Jon Elster, 2000).

Kembali pada masalah sosialisme-ilmiah, harus kami tegaskan bahwa sesungguhnya sosialisme Marx sama sekali bukanlah hukum teoritis, dalam artian menganjurkan untuk mencari kebenaran akhir dari ilmu pengetahuan yang intinya adalah pengetahuan manusia, sejarah, dan penemuan-penemuannya. Namun ia merupakan refleksi dari kegelisahan intelektual seorang Marx atas hal-hal paradoks yang mewarnai realitas sosial. Dari sini kemudian ia muncul ke permukaan sebagai sebuah gerakan nyata yang didasarkan pada sebuah ideologi pemikiran yang mencerminkan pemahaman seorang Marx akan kondisi masyarakat beserta aspek-aspek perkembangannya. Sehingga apa yang ia munculkan sebenarnya bukanlah sebuah teori ilmu pengetahuan tentang masyarakat, melainkan sebuah rencana panjang perubahan sosial yang ia tuangkan dalam wadah program berdasarkan hukum-hukum rasio-ilmiah.

Jika sebelumnya disebutkan bahwa Marx menolak jika sosialisme-ilmiah-nya didasarkan pada pertimbangan-pertimbangan moral, maka sesungguhnya hal tersebut bukan berarti Marx melegalkan anarkisme dalam gerakannya. Penolakan tersebut akan lebih tepat jika dikatakan sebagai upaya Marx dalam menempatkan ideologi pemikirannya pada ruang perspektif yang ia bangun. Dalam artian, sosialisme-ilmiah yang dimaksud Marx adalah sebuah tujuan yang secara niscaya akan muncul sebagai komplikasi dari hukum perkembangan masyarakat. Jadi sekali lagi, sebenarnya Marx tidak menolak keluhuran nilai moralitas, ia hanya menegaskan bahwa sosialisme-ilmiah-nya merupakan implikasi logis dari mekanisme evolusi sosial tanpa harus mengaitkannya dengan segala bentuk pertimbangan moral. Dan tentu kenyataan ini bukanlah sebuah alasan bagi kita 
untuk dapat mengatakan bahwa gerakan Marxis identik dengan anarkisme yang tidak lagi mengindahkan nilai etika-moral. Namun dalam hal ini Marx hanya melakukan 'penolakan' secara epistemologis saja, sementara secara substansial ia justru sangat menjaga keutuhan nilai moralitas. Ini terbukti melalui pernyataannya yang tertuang dalam Manifesto Komunis, bahwa kekuasaan yang didapatkan oleh para kelas pekerja pada akhirnya 'harus' melahirkan "moral-massa" agar sesuai dengan program yang rasional, di mana kebebasan bagi setiap manusia merupakan syarat bagi kebebasan masyarakat. (Andi Muawiyah Ramly, 2013).

Dari pemahaman tersebut, akhirnya kita akan sampai pada sebuah pulau kesadaran bahwa sosialisme-ilmiah lebih merupakan cita-cita mulia dari seorang Marx yang mana ia berupaya menempatkan para kelas pekerja pada perspektif kemanusiaannya. Ia ingin mengajak kita semua untuk sama-sama mewujudkan sebuah cita-cita universal, yakni "manusia yang mampu menumbuhkan dan mengembangkan dirinya sendiri secara sempurna dalam kerja". Untuk lebih menegaskan ketinggian cita-cita Marx ini, maka kami ingin menutup bagian ini dengan mengutip penjelasan Frederick Engels, sahabat setia Marx, dalam bukunya Socialism: Utopian and Scientific,

Sosialisme adalah ungkapan tentang kebenaran, pendapat, dan keadilan mutlak...dengan melepasnya dari ikatan ruang, waktu, dan perkembangan sejarah umat manusia. Ia merupakan esensi dari wahyu Ilahi atau sebab yang tetap (tak berubah)... Pentingnya bukan terletak pada menciptakan sistem sosial lengkap yang bisa dilakukan semaksimal mungkin, melainkan terletak pada pengkajian tentang pertumbuhan historis dalam ekonomi yang dibentuk oleh kualitas kepentingan kelas pekerja beserta perjuangannya, dan dalam menemukan saranasarana dalam menyelesaikan pertentangan di tengah-tengah kondisi perekonomian yang berbeda pada tingkat pertumbuhan. (Franz Magnis Suseno, 2013).

\section{B. Sosio-ekonomi: Kristalisasi nilai-nilai transenden dalam menciptakan kesejahteraan sosial}

Dalam tradisi keilmuan Islam, al-Ghazali dikenal sebagai seorang ilmuan yang cukup komplit. Kepiawannya dalam beraneka ragam bidang keilmuan, membuat para ulama' lain yang hidup dimasanya tidak sidikitpun merasakan keraguan untuk menjulukinya sebagai Sang Hujjatul Islam. Dari apa yang telah kita telusuri tentang pemikiran sosio-ekonominya, kita dapat melihat kontruksi pemikiran al-Ghazali yang 
begitu kental dengan nuansa sufistik. Hal ini tentu tak lepas dari latar belakang pribadinya yang setelah mengalamai masa-masa 'skeptis intelektual', ia memilih jalan kehidupan asketik dalam mencari kebenaran. (M. Umer Chapra, 2000).

Apa yang didemonstrasikan al-Ghazali melalui konsep sosio-ekonominya, sesungguhnya berlatar dari sense of intellect-nya yang secara historis memiliki kesamaan 'atmosfer' dengan apa yang dialami Marx. Ia muncul ke permukaan atas dasar dorongan tanggung jawab sosialnya yang tak bisa menerima begitu saja adanya kesenjangan sosialekonomi akibat ekploitasi besar-besaran dari pihak-pihak tertentu. Satu fakta yang menurut pandangannya telah menjadi sesuatu yang sangat ironis, adalah kenyataan hilangnya apresiasi para pelaku ekonomi akan kemegahan nilai-nilai etika religius. Sehingga apa yang menjadi titik signifikansi dari pemikiran al-Ghazali ialah terletak pada upaya perbaikan akhlak, baik dalam ruang lingkup personal maupun komunal. (Yusuf Qardlawi, 2011).

Menurut al-Ghazali, setiap aktivitas ekonomi yang diperagakan oleh siapapun haruslah memiliki semangat untuk mewujudkan kemashlahatan. Dalam hal ini, lebih lanjut ia menegaskan bahwa upaya mewujudkan kemashlahatan tersebut haruslah bermuara pada pemeliharaan Maqaasid al-Syari'ah al-Khamsah, yakni agama, jiwa, akal, keturunan dan harta. Di sini kita dapat menangkap bahwa konsep sosio-ekonomi yang ditawarkan al-Ghazali lebih mengarah pada paradigma klasik Teosentrisme. Ia berpendapat bahwa setiap aktivitas manusia, baru akan melahirkan mashlahah bila mampu merefleksikan idealitas ketuhanan yang tertuang dalam ketentuan syari'at. Sebab pada dasarnya Tuhan lebih mengerti apa yang manusia butuhkan, sehingga segala bentuk kebijakanNya tiada lain bertujuan untuk menjaga manusia agar tetap berada dalam ruang fitrahnya sebagai makhluk mulia.

Namun demikian, kita tidak boleh terjebak pada pola pikir dualistik ala Aristotelianisme dengan memberikan pemisahan yang curam antara Teosentris dan Antroposentris. Jika hal tersebut kita lakukan, maka kita telah menyeret konsep yang ditawarkan al-Ghazali pada belenggu 'alienasi intelektual' yang akan kehilangan nilai praksisnya. Oleh karena itu, kita harus memahami bahwa sebenarnya al-Ghazali tidak bermaksud memisahkan idealitas Tuhan dan idealitas manusia pada ruang perspektif yang sama sekali berbeda. Justru ia memandang bahwa idealitas manusia merupakan cerminan 
dari idealitas Tuhan. Sehingga upaya untuk mewujudkan kemashlahatan bagi umat manusia merupakan second derivation dari upaya pemeliharaan Maqaasid al-Syari'ah al-Khamsah. Jadi Teosentrisme al-Ghazali sama sekali tidak bermaksud untuk mengebiri kemerdekaan manusia dalam berkreativitas demi meningkatkan kualitas hidupnya. Ia hanya menginginkan bagaimana perilaku ekonomi masyarakatnya senantiasa sesuai dengan harmoni yang dicita-citakan agama secara seimbang. (Ibrahim Muhammad Mahmud AlHariri, 1998).

Hal tersebut menjadi semakin jelas ketika al-Ghazali mengecam secara lantang mereka yang mencukupkan usaha ekonominya hanya pada lingkaran saddu al-ramaq, yakni hanya untuk menyambung hidupnya saja tanpa adanya keinginan untuk meningkatkan kualitas hidupnya secara paripurna. Hal ini didasarkan pada sebuah keyakinan bahwa kesejahteraan sosial merupakan akumulasi dari kesejahteraan individu. Sehingga adanya kesadaran untuk berkembang dari setiap individu merupakan sesuatu yang niscaya adanya demi terciptanya tatanan sosial yang benar-benar ideal. Dalam tataran selanjutnya, kelestarian agama bisa saja terancam bila tatanan sosial yang ada telah bergeser dari titik keseimbangannya. Tentu hal ini pun bergantung pada bagaiamana setiap individu menjalankan perannya untuk bersama-sama menciptakan pola hidup yang sesuai dengan tendensi nilai etika-moral. Karena itulah kemudian al-Ghazali menegaskan bahwa kegiatan ekonomi merupakan satu dimensi dari pemenuhan tugas keagamaan seseorang, sehingga adanya apresiasi yang kuat terhadap ideal-ideal syari'at harus menjadi kemestian bagi setiap pelaku ekonomi. (Jamaluddin Athiyyah, 2001).

Akhirnya, sosio-ekonomi yang ditawarkan al-Ghazali merupakan sebuah konsep normatif yang merefleksikan keinginan al-Ghazali dalam upaya mewujudkan pola kehidupan sosial-ekonomi yang benar-benar seimbang dengan dilandasi keluhuran nilai etika religius yang transenden.

\section{Antara Sosialisme-ilmiah Karl Marx dan Sosio-ekonomi Al-Ghazali}

Dari apa yang telah kita telusuri tentang pemikiran Karl Marx dan al-Ghzali, dapat kita ketahui dua karakter pemikiran dengan ciri khas masing-masing yang pada dasarnya memiliki titik signifikansi yang nyaris serupa. Marx dengan sosialisme-ilmiahnya berupaya sekuat tenaga untuk membebaskan para kelas bawahan (baca: kaum buruh/kelas 
pekerja) dari belenggu alienasi sosial-ekonomi. Dengan lantang Marx menolak dan menentang habis-habisan adanya kepemilikan pribadi atas faktor-faktor produksi, yang mana kenyataan tersebut telah membuat para kelas pekerja menjadi terasing dari identitasnya sendiri. 'Kerja' yang seharusnya menjadi sarana proses objektivasi bagi eksistensi manusia -yang karena itu semestinya para kelas pekerja mendapatkan posisi yang layak dan lebih terhormat- pada kenyataannya justru mengantarkan mereka (para kaum buruh) pada jurang ketidakadilan akibat eksploitasi sosial-ekonomi yang muncul dari dominasi para pemilik modal. Kenyataan inilah yang tak bisa diterima begitu saja oleh Marx, yang kemudian secara frontal ia menerjemahkan kegelisahan intelektualnya tidak hanya ke dalam sebuah ideologi pemikiran, namun ia wujudkan pula ke dalam gerakan nyata.

Lain halnya dengan soisalisme-ilmiah Marx, kontruksi pemikiran sosio-ekonomi yang al-Ghazali tawarkan justru lebih murni sebagai sebuah pemikiran yang bersifat normatif dan tidak melembaga kedalam sebuah gerakan sosial. Secara jelas kita dapat melihat karakter yang membuat pemikiran al-Ghazali berbeda dengan Marx adalah terletak pada kecenderungan al-Ghazali untuk mengedepankan nilai-nilai etika religius dalam meracik formula pemikirannya. Menurtnya, keseimbangan dalam kehidupan sosialekonomi tadak akan cukup jika hanya mangandalkan kesadaran eksistensial dari setiap individu dan kelompok masyarakat tertentu, akan tetapi adanya apresiasi yang tinggi akan kemegahan nilai-nilai religius juga menjadi faktor yang sangat menentukan dalam mewujudkan kesejahteraan sosial. Jadi, kegiatan ekonomi yang didasarkan pada kesadaran Ilahiah nampaknya menjadi puncak destinasi dari pemikiran sosio-ekonomi al-Ghazali.

Namun secara umum kita dapat melihat bahwa antara kedua tokoh besar tersebut, secara historis terdapat titik persamaan yang melatarbelakangi munculnya pemikiran keduanya, yaitu sebuah motif yang kemudian lahir sebagai refleksi dari kegelisahan intelektual seorang pemikir akan adanya ketidakadilan sosial yang kita sebut sebagai 'kegundahan realitas'. Marx dan al-Ghazali sama-sama menekankan adanya penghargaan terhadap potensi individual para korban eksploitasi sosial-ekonomi demi membebaskan mereka dari belenggu keterasingan yang muncul akibat curamnya kesenjangan sosialekonomi antara kaum kaya dan masyarakat bawah. 


\section{KESIMPULAN}

Sebagai pamungkas dari kajian ilmiah ini, maka berikut kami sajikan kesimpulankesimpulan yang merupakan hasil dari analisis kami terhadap data-data yang secara jujur dan objektif menampilkan wajah pemikiran sosialisme-ilmiah Karl Marx dan pemikiran sosio-ekonomi al-Ghazali. Kendatipun kami tidak bisa mengklaim bahwa hasil dari analisis ini merupakan sebuah produk kajian yang telah mencapai titik finalnya, namun setidaknya ada beberapa hal penting yang akhirnya harus kami katakan sebagai 'kesimpulan' dari proyek penelitian ini, yaitu:

1. Soslialisme-ilmiah Karl Marx merupakan paham sosialisme yang bertujuan untuk mewujudkan keadilan sosial-ekonomi bagi para kelas pekerja yang didasarkan atas pengetahuan objektif tentang hukum-hukum perkembangan masyarakat. Sosialismeilmiah bukanlah konsep ilmu yang harus didefinisikan, akan tetapi ia lebih merupakan sebuah cita-cita yang hendak menempatkan manusia pada perspektif yang sebenarnya, yakni manusia yang menciptakan sarana-sarana ekonomi, politik dan peradaban, di mana manusia mampu menumbuhkan dan mengembangkan dirinya sendiri secara sempurna dalam aktivitas kerja.

2. Sosio-ekonomi al-Ghazali merupakan konsep pemikiran yang lebih bersifat normatif, yang didalamnya menekankan adanya apresiasi yang tinggi terhadap nilai-nilai etika religius dalam melaksanakan kegiatan ekonomi. Yakni sebuah konsep ekonomi yang menjadikan mashlahah sebagai tujuan utamanya dengan berlandaskan pada pemeliharaan Maqaashid al-Syari'ah al-Khamsah.

3. Titik persamaan antara pemikiran sosialisme-ilmiah Karl Marx dan sosio-ekonomi alGhazali adalah keduanya sama-sama menekankan adanya penghargaan terhadap potensi dasar manusia untuk mengembangkan dirinya dalam upaya mewujudkan keadilan sioalekonomi terutama bagi masyarakat lapisan bawah. Sementara titik perbedaannya adalah bahwa sosialisme-ilmiah Marx didasarkan pada penyelidikan historis dan pengetahuan objektif tentang hukum-hukum perkembangan masyarakat dan ia lahir sebagai sebuah gerakan nyata. Sedangkan sosio-ekonomi al-Ghazali lebih didasarkan pada nilai-nilai etika religius yang terkandung dalam ideal-ideal syari'at dan murni sebagai sebuah pemikiran yang tidak melembaga ke dalam gerakan sosial. 
Volume 2, No 2, Agustus 2021 


\section{DAFTAR PUSTAKA}

Anto, Hendrie, M. B. Pengantar Ekonomika Mikro Islam. Yogyakarta : Ekonisia, 2013.

Athiyyah, Jamaluddin. Nahwa Taf'ili Maqosidi al-Syar'iyyah., Damsyik-Suriah : Darul Fikri, 2001.

Beilharz, Peter. Teori-teori Sosial (Observasi Kritis terhadap Para Filosof Terkemuka). Yogyakarta : Pustaka Pelajar, 2012.

Chapra, M. Umer. Sistem Moneter Islam. Jakarta : Gema Insani Press, 2000.

Elster, Jon. Karl Marx (Marxisme-Analisis Kritis). Jakarta : Prestasi Pustakaraya, 2000.

Ghazali (al), Abu Hamid. Ihya’ Ulum al-Din. Semarang : Thaha Putra, t.t. Majmu’atu Rosaili al-Imam Al-Ghazali. Beirut : Darul Fikri, 1996. Sirr al-'Alamain wa Kasyf Ma fi al-Darain. Yogyakarta : Pustaka Sufi, 2003.

Hariri (al), Ibrahim Muhammad Mahmud. al-Madkhal ila al-Qawa'idi al-Fiqhiyyah alKulliyyah. Yordania : Daru 'Ammar, 1998.

Karim, Adiwarman Azwar. Ekonomi Islam (Suatu Kajian Kontemporer). Jakarta : Gema Insani Press, 2013. Sejarah Pemikiran Ekonomi Islam. Jakarta : Raja Grafindo Persada, 2012.

M. T. Ritonga, dkk. Pelajaran Ekonomi 3. Jakarta : Erlangga, 2000.

Marthon, Said Sa'ad. Ekonomi Islam di Tengah Krisis Ekonomi Global. Jakarta : Zikrul Hakim, 2017.

Munir, Misbahul dan Djalaluddin, A. Ekonomi Qur'ani: Doktrin Reformasi dalam AlQur'an. Malang : UIN Malang Press, 2014.

Noor, Fauz. Semesta Sabda (Sebuah Novel Filsafat). Yogyakarta : LKiS, 2015.

Tapak Sabda (Sebuah Novel Filsafat). Yogyakarta : LKiS, 2012.

Qardlawi, Yusuf. Peran Nilai dan Moral dalam Perekonomian Islam. Jakarta : Robbani Press, 2011.

Rahman, Afzalur. Doktrin Ekonomi Islam (Jilid I). Yogyakarta : PT Dana Bhakti Wakaf, 2015.

Ramly, Andi Muawiyah. Peta Pemikiran Karl Marx (Materialisme Dialektis dan Materialisme Historis). Yogyakarta : LKiS, 2013. 
Volume 2, No 2, Agustus 2021

Suseno, Franz Magnis. Pemikiran Karl Marx (Dari Sosialisme Utopis ke Perselisihan Sosialisme). Jakarta : PT Gramedia Pustaka Utama, 2013. 